\title{
25 Research Soure \\ Innovative Method for Amplatzer Device Implantation in Patients With Bronchopleural Fistulas
}

Jisong Zhang

Sir Run Run Hospital of Zhejiang University

Huihui Hu

Sir Run Run Shaw hospital of Zhejiang University

Li Xu

Sir Run Run Shaw hospital of Zhejiang Univeristy

Shan Xu

Sir Run Run Shaw hospital of Zhejiang University

Jihong Zhu

Sir Run Run Shaw hospital of Zhejiang University

\section{Fengjie Wu}

The Second Hospital of Jiaxing

Enguo Chen ( $\square$ 3195024@zju.edu.cn )

Zhejiang University School of Medicine Sir Run Run Shaw Hospital https://orcid.org/0000-0003-2338-8610

\section{Research article}

Keywords: Bronchopleural fistula, Amplatzer devices, Pulmonary intervention, Bronchoscopy, Sheath-free method

Posted Date: December 1st, 2020

DOI: https://doi.org/10.21203/rs.3.rs-116173/v1

License: (9) (i) This work is licensed under a Creative Commons Attribution 4.0 International License. Read Full License 


\section{Abstract}

Background: Bronchopleural fistula (BPF) is a relatively rare complication after various types of pulmonary resection. The double-sided mushroom-shaped occluder (Amplatzer device, AD) has been gradually used for BPF blocking due to its reliable blocking effect. We have improved the existing AD implantation methods to facilitate clinical use and named the new approach the Sheath-free method (SFM the aim of the present report was to explore the reliability and advantages of SFM for AD implantation.

Methods: We improved the existing placement methods by abandoning the sheath of the $A D$ and using the working channel of the bronchoscope to directly store or release the AD without the use of general anesthesia, rigid bronchoscopy, fluoroscopy, or bronchography. A total of 6 patients (5 men and 1 woman, aged $66.67 \pm 6.19$ years [mean \pm SD]) had bronchopleural fistulas sealed using the SFM for AD implantation.

Results: Closure was successfully performed in all 6 patients with the SFM, and the average duration of operation was 16.17 minutes $(16.17 \pm 4.67$ minutes [mean \pm SD]). Five patients achieved complete occlusion after the operation, and 1 patient who had multiple fistulas did not. No patients died due to operation complications and BPF recurrence. The average follow-up time was 13.2 months (range: 10-17 months).

Conclusion: We observed that the SFM for AD implantation-with accurate device positioning and a clear field of vision-is efficient and convenient. The AD is effective in BPF sealing, and patient symptoms significantly improved after sealing.

\section{Background}

Bronchopleural fistula (BPF) is a serious complication that occurs after various types of pulmonary resection.

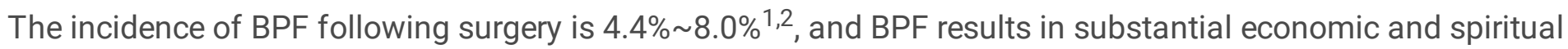
burden for patients ${ }^{3,4}$. Risk factors ${ }^{5}$ include preoperative neoadjuvant chemotherapy, operations on the right side, and complete pneumonectomy. Once the complication appears, it is often difficult to treat, and the mortality rate ranges from $18-50 \% 3,4$.

BPF is based on comprehensive treatment, including closed thoracic drainage, prolonged antibiotic use, symptomatic supportive treatment, and various fistula blocking methods ${ }^{6}$. Several studies have found that blocking BPF by means of respiratory endoscopy has the advantages of high patient acceptance, low operation risks, low overall costs, and rapid postoperative recovery ${ }^{7,8}$. Endoscopic interventional treatment for BPF currently utilizes two major methods: one is to stimulate the formation of local granulation tissue and scar tissue through various kinds of physical and chemical methods to achieve a blocking effect; the other is to place various types of occluders, including distally closed metal stents, distally closed silicone stents, EBVs(Endobronchial Valves), and Amplatzer devices ${ }^{9-12}$.

Fruchter $\mathrm{O}$ first reported the use of double-sided mushroom umbrella occluders (Amplatzer devices, ADs) or arterial catheter occlusion devices (Amplatzer vascular plugs, AVPs) in treating BPFs ${ }^{13-15}$. Different methods for $A D$ implantation have been reported in previous studies. According to Fruchter $\mathrm{O}, \mathrm{AD}$ s are implanted under direct bronchoscopic and fluoroscopic visualization with the use of guide wires passed through the fistula as aids ${ }^{15,16}$. In China, the common method of placement is using rigid bronchoscopy, or ADs are implanted via tracheal 
intubation with the guidance of bronchoscopy passed through the nasal passage. In the current study, we describe a novel and innovative method (SFM) for AD implantation which makes AD implantation more convenient and effective in clinical use.

\section{Methods}

ADs (Fig. 1) are self-expanding double-sided mushroom umbrella structures woven from nickel-titanium alloy wires with a slender waist in the middle. In this study, we used the Amplatzer devices (VISEE medical Co; Shandong, China). Their sealing disc diameters range from $12 \mathrm{~mm}$ to $56 \mathrm{~mm}$, and waist diameters range from $4 \mathrm{~mm}$ to $38 \mathrm{~mm}$. We often selected models with waist diameters between $6 \mathrm{~mm}$ to $12 \mathrm{~mm}$. The current procedure was carried out at the bronchoscopy operating room in patients under moderate sedation unless they were already mechanically ventilated. Patients received topical anesthesia with lidocaine, dextromethorphan and remifentanil continuously administered for maintenance. After sedation, bronchoscopy was used to evaluate fistulas and select the AD model.

The innovation in SFM is the use of a bronchoscopy working channel to replace the sheath tube of the AD. An Olympus T series endoscopy (model Bf-it290, outer diameter of $5.9 \mathrm{~mm}$ and a working channel of $2.8 \mathrm{~mm}$, Olympus Corp, Tokyo, Japan) was selected for implantation. The guide wire (diameter of $1.9 \mathrm{~mm}$ ) was inserted into the working channel of the bronchoscope. After it extended out of the working channel, it was connected to the $A D$, so that the $A D$ can be received or released by drawing the guide wire. The release process was performed directly under the bronchoscope, with a clear field of vision, and it could be adjusted by drawing the guide wire at any time until it was satisfactory. Upon reaching a satisfactory position, the device was detached. The bronchoscope were removed from the airway, and the patient was transferred to the recovery room. The device can be placed through the nasal passage, a tracheal tube, a laryngeal mask, or a rigid bronchoscopy depending on the patient's personal circumstances. Figures of procedures are presented in Fig. 2.

\section{Results}

In total, 6 patients ( 5 men and 1 woman, aged $66.67 \pm 6.19$ years [mean \pm SD]) were treated in our center with bronchoscopy AD implantation between October 2018 and May 2019. The main etiology for BPF was pneumonectomy $(n=3)$ or lobectomy $(n=3)$. The underlying disease was primary lung cancer $(n=6)$. Before AD implantation, all patients needed to report to the hospital ethics committee for approval, and then they were informed of the study procedures and signed informed consent and off-label use consent forms. The demographic and treatment data for the study participants are presented in Table 1 and Table 2. The average follow-up time for all patients was 13.2 months (range: 10-17 months). All 6 patients underwent AD placement with the use of the SFM, and the average duration of operation was 16.17 minutes $(16.17 \pm 4.67$ minutes [mean $\pm \mathrm{SD}])$. Closure was successfully performed in all 6 patients. There were no immediate complications related to the procedure, and all patients were discharged within 24 hours except for patient No. 3, who underwent closure in the ICU (intensive care unit) and had severe pneumonia of the residual right lung. Although this patient was observed to have a significant reduction in air leakage after AD implantation, he eventually died on postoperative day 3 due to complications of severe pneumonia. 
Table 1

Patient characteristics and treatment data

\begin{tabular}{|c|c|c|c|c|c|c|}
\hline $\begin{array}{l}\text { Serial } \\
\text { number }\end{array}$ & Sex/Age(year) & Operative site & Disease & $\begin{array}{l}\text { Onset } \\
\text { time of } \\
\text { BPF }\end{array}$ & $\begin{array}{l}\text { Location } \\
\text { of BPF }\end{array}$ & $\begin{array}{l}\text { Indwelling } \\
\text { time of } \\
\text { drainage } \\
\text { tube }\end{array}$ \\
\hline 1 & $F / 73$ & $\begin{array}{l}\text { Lower right } \\
\text { lobectomy }\end{array}$ & Adenocarcinoma & $\begin{array}{l}8 \text { months } \\
\text { after } \\
\text { operation }\end{array}$ & $\begin{array}{l}\text { Right } \\
\text { Lower } \\
\text { bronchus }\end{array}$ & 2 months \\
\hline 2 & $M / 64$ & $\begin{array}{l}\text { Lower right } \\
\text { lobectomy }\end{array}$ & $\begin{array}{l}\text { Squamous cell } \\
\text { carcinoma }\end{array}$ & $\begin{array}{l}20 \text { days } \\
\text { after } \\
\text { operation }\end{array}$ & $\begin{array}{l}\text { Right } \\
\text { Lower } \\
\text { bronchus }\end{array}$ & 15 days \\
\hline 3 & $M / 66$ & $\begin{array}{l}\text { Left } \\
\text { pneumonectomy }\end{array}$ & $\begin{array}{l}\text { Squamous cell } \\
\text { carcinoma }\end{array}$ & $\begin{array}{l}9 \text { days } \\
\text { after } \\
\text { operation }\end{array}$ & $\begin{array}{l}\text { Left } \\
\text { Main } \\
\text { bronchus }\end{array}$ & 2 months \\
\hline 4 & $\mathrm{M} / 71$ & $\begin{array}{l}\text { Upper left } \\
\text { lobectomy }\end{array}$ & $\begin{array}{l}\text { Squamous cell } \\
\text { carcinoma }\end{array}$ & $\begin{array}{l}40 \text { days } \\
\text { after } \\
\text { operation }\end{array}$ & $\begin{array}{l}\text { Upper } \\
\text { left } \\
\text { bronchus }\end{array}$ & 20 days \\
\hline 5 & $\mathrm{M} / 70$ & $\begin{array}{l}\text { Right } \\
\text { pneumonectomy }\end{array}$ & $\begin{array}{l}\text { Non-small-cell } \\
\text { lung cancer }\end{array}$ & $\begin{array}{l}1-2 \\
\text { months } \\
\text { after } \\
\text { operation\# }\end{array}$ & $\begin{array}{l}\text { Right } \\
\text { main } \\
\text { bronchus }\end{array}$ & 23 years \\
\hline 6 & $\mathrm{M} / 56$ & $\begin{array}{l}\text { Right middle lobe } \\
\text { and right lower } \\
\text { lobe lobectomy }\end{array}$ & $\begin{array}{l}\text { Squamous cell } \\
\text { carcinoma }\end{array}$ & $\begin{array}{l}1 \text { month } \\
\text { after } \\
\text { operation }\end{array}$ & $\begin{array}{l}\text { Right } \\
\text { middle } \\
\text { and } \\
\text { lower } \\
\text { bronchi }\end{array}$ & 2 months \\
\hline
\end{tabular}


Table 2

Operation and follow-up information of 6 patients

\begin{tabular}{|c|c|c|c|c|c|c|c|c|}
\hline $\begin{array}{l}\text { Serial } \\
\text { number }\end{array}$ & $\begin{array}{l}\text { Location } \\
\text { of BPF }\end{array}$ & $\begin{array}{l}\text { Fistula } \\
\text { diameter }\end{array}$ & $\begin{array}{l}A D \\
\text { model }\end{array}$ & $\begin{array}{l}\text { Duration } \\
\text { of } \\
\text { operation }\end{array}$ & $\begin{array}{l}\text { Completely } \\
\text { blocked }\end{array}$ & $\begin{array}{l}\text { Removed } \\
\text { drainage } \\
\text { tube }\end{array}$ & $\begin{array}{l}\text { Time from } \\
\text { closure to } \\
\text { extubation }\end{array}$ & $\begin{array}{l}\text { Follow- } \\
\text { up time }\end{array}$ \\
\hline 1 & $\begin{array}{l}\text { Right } \\
\text { Lower } \\
\text { bronchus }\end{array}$ & $10 \mathrm{~mm}$ & $\begin{array}{l}22-10- \\
24 \mathrm{~mm}\end{array}$ & $10 \mathrm{~min}$ & Yes & Yes & 3 days & $\begin{array}{l}17 \\
\text { months }\end{array}$ \\
\hline 2 & $\begin{array}{l}\text { Right } \\
\text { Lower } \\
\text { bronchus }\end{array}$ & $8 \mathrm{~mm}$ & $\begin{array}{l}16-8- \\
20 \mathrm{~mm}\end{array}$ & $15 \mathrm{~min}$ & Yes & Yes & 3 months & $\begin{array}{l}15 \\
\text { months }\end{array}$ \\
\hline 3 & $\begin{array}{l}\text { Left } \\
\text { Main } \\
\text { bronchus }\end{array}$ & $10 \mathrm{~mm}$ & $\begin{array}{l}23-12- \\
27 \mathrm{~mm}\end{array}$ & $18 \mathrm{~min}$ & Yes & No & NA & NA \\
\hline 4 & $\begin{array}{l}\text { Upper } \\
\text { left } \\
\text { bronchus }\end{array}$ & $8 \mathrm{~mm}$ & $\begin{array}{l}16-8- \\
20 \mathrm{~mm}\end{array}$ & $20 \mathrm{~min}$ & Yes & Yes & 2 months & $\begin{array}{l}12 \\
\text { months }\end{array}$ \\
\hline 5 & $\begin{array}{l}\text { Right } \\
\text { main } \\
\text { bronchus }\end{array}$ & 10 mm & $\begin{array}{l}22-10- \\
24 \mathrm{~mm}\end{array}$ & $22 \mathrm{~min}$ & Yes & $\begin{array}{l}\text { Follow- } \\
\text { up }\end{array}$ & NA & $\begin{array}{l}12 \\
\text { months }\end{array}$ \\
\hline 6 & $\begin{array}{l}\text { Right } \\
\text { middle } \\
\text { and } \\
\text { lower } \\
\text { bronchi }\end{array}$ & $\begin{array}{l}\text { Several } \\
\text { small } \\
\text { fistulas }\end{array}$ & $\begin{array}{l}23-12- \\
27 \mathrm{~mm}\end{array}$ & $12 \mathrm{~min}$ & No & Yes* & $N A^{*}$ & $\begin{array}{l}10 \\
\text { months }\end{array}$ \\
\hline \multicolumn{9}{|c|}{$\begin{array}{l}\text { \# Although patient No. } 3 \text { underwent closure in the ICU with respiratory failure was observed to have a } \\
\text { significant reduction in air leakage after AD implantation, he eventually died on the third postoperative day } \\
\text { due to complications from severe pneumonia. }\end{array}$} \\
\hline
\end{tabular}

After receiving the occlusion surgery, 5 patients achieved complete occlusion (all except for patient No. 6), and symptoms related to the BPFs disappeared following closure with the AD. Three of 5 patients with complete occlusion removed the thoracic drainage tube. Patient No. 6 whose bronchoscopy showed multiple micro fistulas at the end of the right middle bronchus received $A D$ closure, but we observed persistent air leakage in the water seal drainage bottle at 6 months after AD implantation. Finally, the patient underwent thoracoscopic free anterolateral thigh flap sealing, and his drainage tube was removed one week after surgery. No patients died due to operation complications and BPF recurrence.

Follow-up evidence showed a definite blocking effect of AD placement improvement of patient symptoms. The first improvement after AD placement was reduced in phlegm volume, followed by reduced cough symptoms. After 3 months of follow-up, improvements in the overall condition, such as improvements in exercise tolerance, weight gain, improved stomach intake, and a more positive attitude, were often observed. Representative figures of study patients are presented in Figs. 3-4. \# Although patient No. 3 underwent closure in the ICU with 
respiratory failure was observed to have a significant reduction in air leakage after AD implantation, he eventually died on the third postoperative day due to complications from severe pneumonia.

* Patient No. 6 underwent thoracoscopic flap sealing after closure failure of AD implantation, and his drainage tube was removed one week after surgery.

\section{Discussion}

We present an innovative method (SFM) for AD implantation for the first time and indicate its feasibility and advantages in clinical practice. Six BPF patients who were suitable for AD implantation were screened, all patients underwent $A D$ placement with the use of SFM, and no cases failed. The advantages we observed with SFM over other methods include easy steps, short operation time, few complications, and ease of reaching the fistula for closure. In our shortest implantation, the whole operation only lasted 10 minutes (Patient No. 1 in Table 2). Postoperative CT showed that the accuracy of AD implantation with SFM was also favorable (Fig. 2). Previous studies have reported one case of failed implantation ${ }^{13}$. In this case, AD fell into the pleural cavity, and the cause may be related to severe infection around the fistula. It is not easy to accurately place an $A D$ into the fistula, especially for fistulas in the upper lobe, which are hard to reach. Tedde ML reported a case with right upper lobe BPF who received AD implantation introduced by sheath which was advanced over the guidewire in the working channel in a 60-minute procedure ${ }^{17}$. In our study, patient No. 4 was a patient with an upper left BPF, and $A D$ implantation required 20 minutes (Patient No. 4 in Table 2). Few scholars have previously presented data on duration of operation, so the average time for $A D$ implantation could not be found as a reference. However, according to the description of operation procedures, such as the need for rigid bronchoscopy or bronchography performance, it is difficult to imagine that the duration of operation is less than 30 minutes. The shorter duration of operation reduces the risk of mechanical ventilation and anesthesia, which is more meaningful for the safety of $A D$ implantation and reducing complications. The disadvantage of SFM is that the requirement of the bronchoscopy working channel should be $2.8 \mathrm{~mm}$ or larger so that the folded $A D$ can be received smoothly. If one wants to place an $A D$ with a large size (for example, 25-14-29 mm or the one described above), the diameter of the AD after folding may be greater than $2.8 \mathrm{~mm}$, which is not suitable for SFM. Additionally, different brands of ADs may have variations in size after folding, which would require attention when operating. In terms of safety, our observations are consistent with previous studies. The technique employed was well tolerated by the patients, with no severe side effects or complications.

\section{Conclusion}

In general, the application prospect of ADs in BPF patients is quite optimistic due to the unique advantages and characteristics of ADs. Meanwhile, as a minimally invasive and effective method, the SFM for AD implantation was safe, convenient and worth spreading.

\section{Abbreviations}

BPF

bronchopleural fistula;

$A D$

Amplatzer device; 
SFM

Sheath-free method;

EBVs

Endobronchial Valves

\section{Declarations}

\section{Ethics approval and consent to participate}

We have obtained the written consent from the patient and Ethics Committee of Sir Run Run Shaw Hospital.

\section{Consent for publication}

The authors declare that they agreed to publish the uploaded video.

\section{Availability of data and materials}

The data and materials in the current study are available from the corresponding author on reasonable request.

\section{Competing interests}

The authors declare that they have no potential conflicts of interest.

\section{Funding}

This study was supported in part by grants from the Jiaxing Municipal Science and Technology Program and Project Management Measures (2017AY33029). The funders did not participate in the designing, performing or reporting in the current study.

\section{Authors' contributions}

JS Z developed the algorithm. $\mathrm{HH} \mathrm{H}$ carried out most of the analyses. $\mathrm{L} X$ participated in the design of the study and helped algorithm development. S X and FJ W drafted the manuscript. JH Z and EG C conceived and coordinated the study. All authors read and approved the final manuscript.

\section{Acknowledgements}

We thank Mrs. Huang Xiaoling, Operating room; Sir Run Shaw Hospital and Mrs. Zhu Meihua, Endoscopic center for their sincere and professional support of our work.

\section{References}

1. Hu XF, Duan L, Jiang GN, Wang H, Liu HC, Chen C. A clinical risk model for the evaluation of bronchopleural fistula in non-small cell lung cancer after pneumonectomy. Ann Thorac Surg. 2013;96(2):419-424.

2. Mazzella A, Pardolesi A, Maisonneuve P, et al. Bronchopleural Fistula After Pneumonectomy: Risk Factors and Management, Focusing on Open-Window Thoracostomy. Semin Thorac Cardiovasc Surg. 
2018;30(1):104-113.

3. Cerfolio RJ. The incidence, etiology, and prevention of postresectional bronchopleural fistula. Semin Thorac Cardiovasc Surg. 2001;13(1):3-7.

4. Sirbu H, Busch T, Aleksic I, Schreiner W, Oster O, Dalichau H. Bronchopleural fistula in the surgery of nonsmall cell lung cancer: incidence, risk factors, and management. Ann Thorac Cardiovasc Surg. 2001;7(6):330-336.

5. Okuda M, Go T, Yokomise H. Risk factor of bronchopleural fistula after general thoracic surgery: review article. Gen Thorac Cardiovasc Surg. 2017;65(12):679-685.

6. Sonobe M, Nakagawa M, Ichinose M, Ikegami N, Nagasawa M, Shindo T. Analysis of risk factors in bronchopleural fistula after pulmonary resection for primary lung cancer. Eur J Cardiothorac Surg. 2000;18(5):519-523.

7. Wu G, Li ZM, Han XW, et al. Right bronchopleural fistula treated with a novel, Y-shaped, single-plugged, covered, metallic airway stent. Acta Radiol. 2013;54(6):656-660.

8. Fruchter O. Innovating customized stents for the treatment of bronchopleural fistula. J Thorac Dis. 2019;11(4):1097-1099.

9. Ranu H, Gatheral T, Sheth A, Smith EE, Madden BP. Successful endobronchial seal of surgical bronchopleural fistulas using BioGlue. Ann Thorac Surg. 2009;88(5):1691-1692.

10. Bellato V, Ferraroli GM, De Caria D, et al. Management of postoperative bronchopleural fistula with a tracheobronchial stent in a patient requiring mechanical ventilation. Intensive Care Med. 2010;36(4):721722.

11. Alazemi S, Chatterji S, Ernst A, Berkowitz D, Michaud G, Majid A. Mediastinal migration of self-expanding bronchial stents in the management of malignant bronchoesophageal fistula. Chest. 2009;135(5):13531355.

12. Chae EY, Shin JH, Song HY, Kim JH, Shim TS, Kim DK. Bronchopleural fistula treated with a silicone-covered bronchial occlusion stent. Ann Thorac Surg. 2010;89(1):293-296.

13. Fruchter O, Kramer MR, Dagan T, et al. Endobronchial closure of bronchopleural fistulae using amplatzer devices: our experience and literature review. Chest. 2011;139(3):682-687.

14. Fruchter O, El Raouf BA, Abdel-Rahman N, Saute M, Bruckheimer E, Kramer MR. Efficacy of bronchoscopic closure of a bronchopleural fistula with amplatzer devices: long-term follow-up. Respiration. 2014;87(3):227-233.

15. Kramer MR, Peled N, Shitrit D, et al. Use of Amplatzer device for endobronchial closure of bronchopleural fistulas. Chest. 2008;133(6):1481-1484.

16. Spiliopoulos S, Krokidis M, Gkoutzios P, et al. Successful exclusion of a large bronchopleural fistula using an Amplatzer II vascular plug and glue embolization. Acta Radiol. 2012;53(4):406-409.

17. Tedde ML, Scordamaglio PR, Minamoto H, Figueiredo VR, Pedra CC, Jatene FB. Endobronchial closure of total bronchopleural fistula with Occlutech Figulla ASD N device. Ann Thorac Surg. 2009;88(3):e25-26.

\section{Figures}




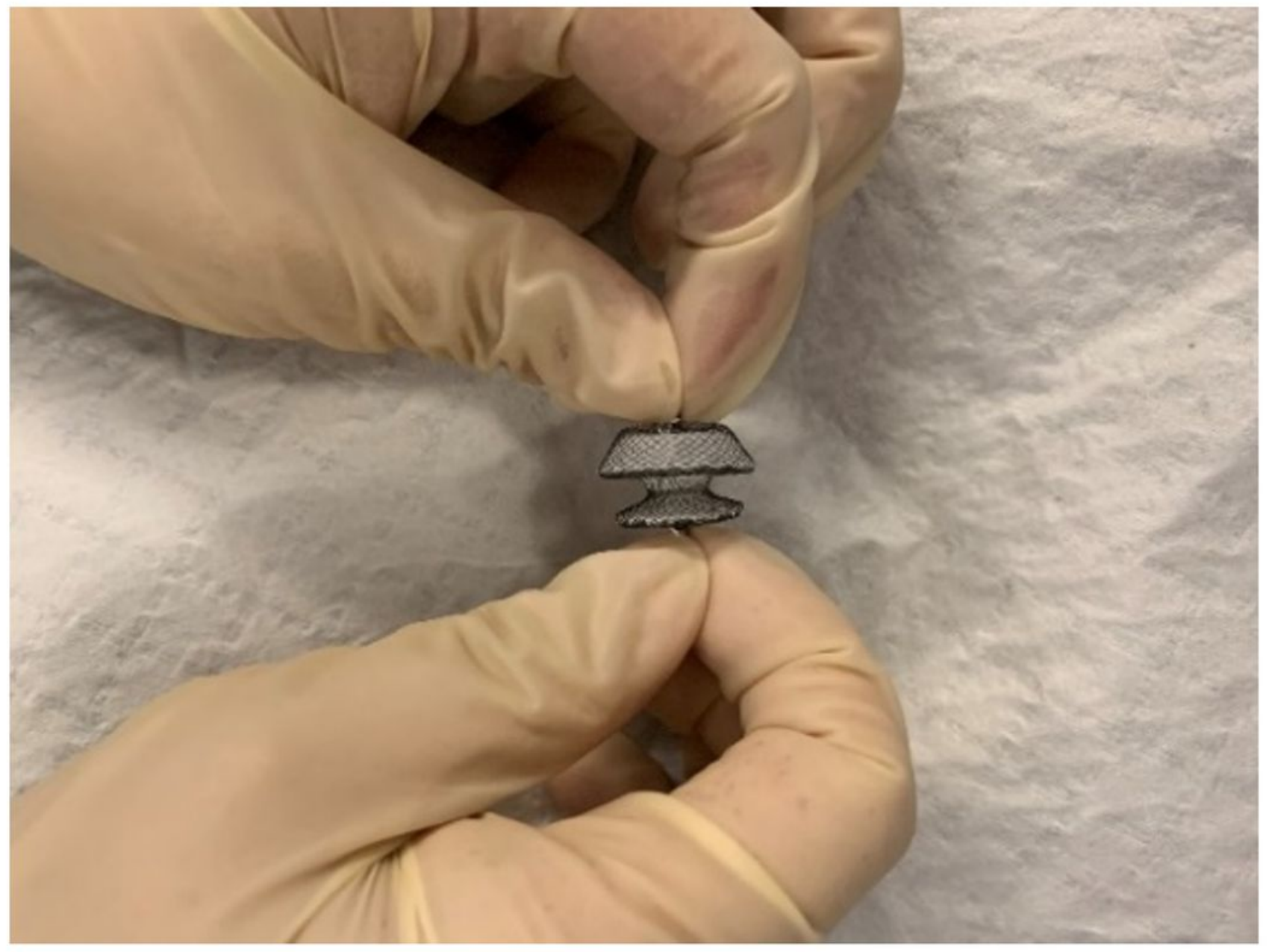

Figure 1

ADs used for bronchoscopic closure of bronchopleural fistulas.

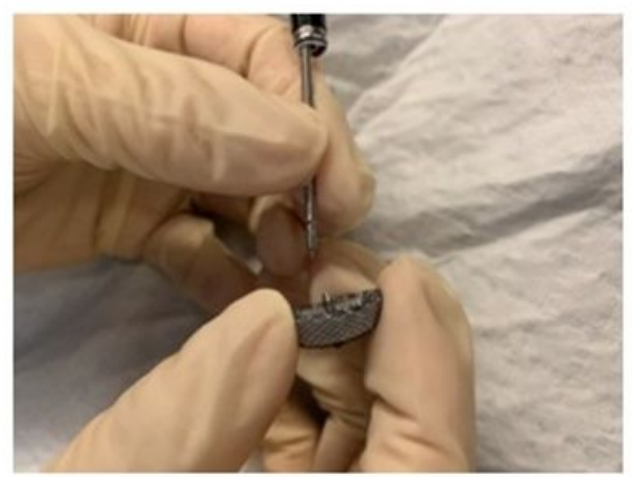

A

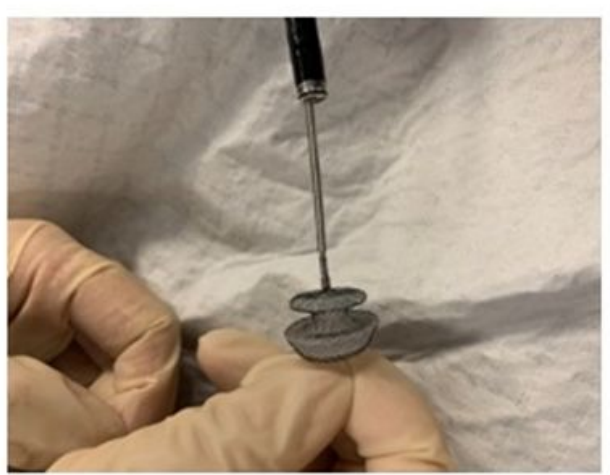

B

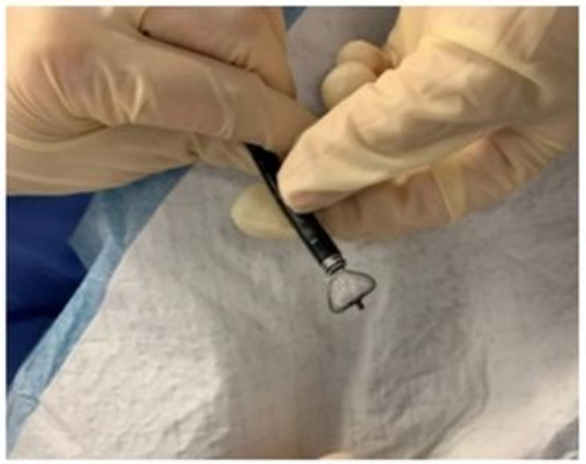

C

Figure 2 
Procedures of the Sheath-free method. A, Guide wire entry through the working channel. $B, A D$ connected to the guide wire. $C, A D$ integrated into the working channel.
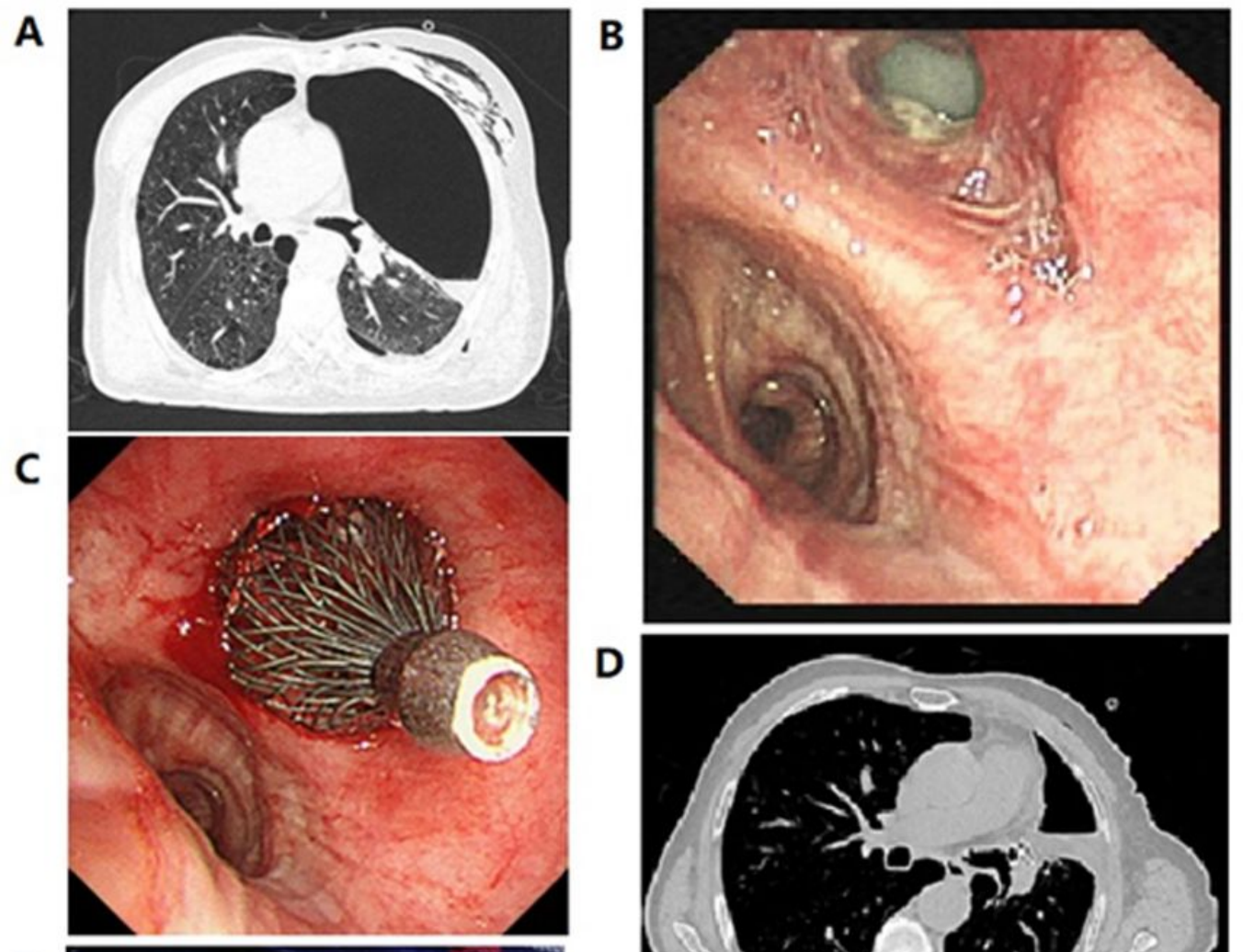

$\mathbf{E}$
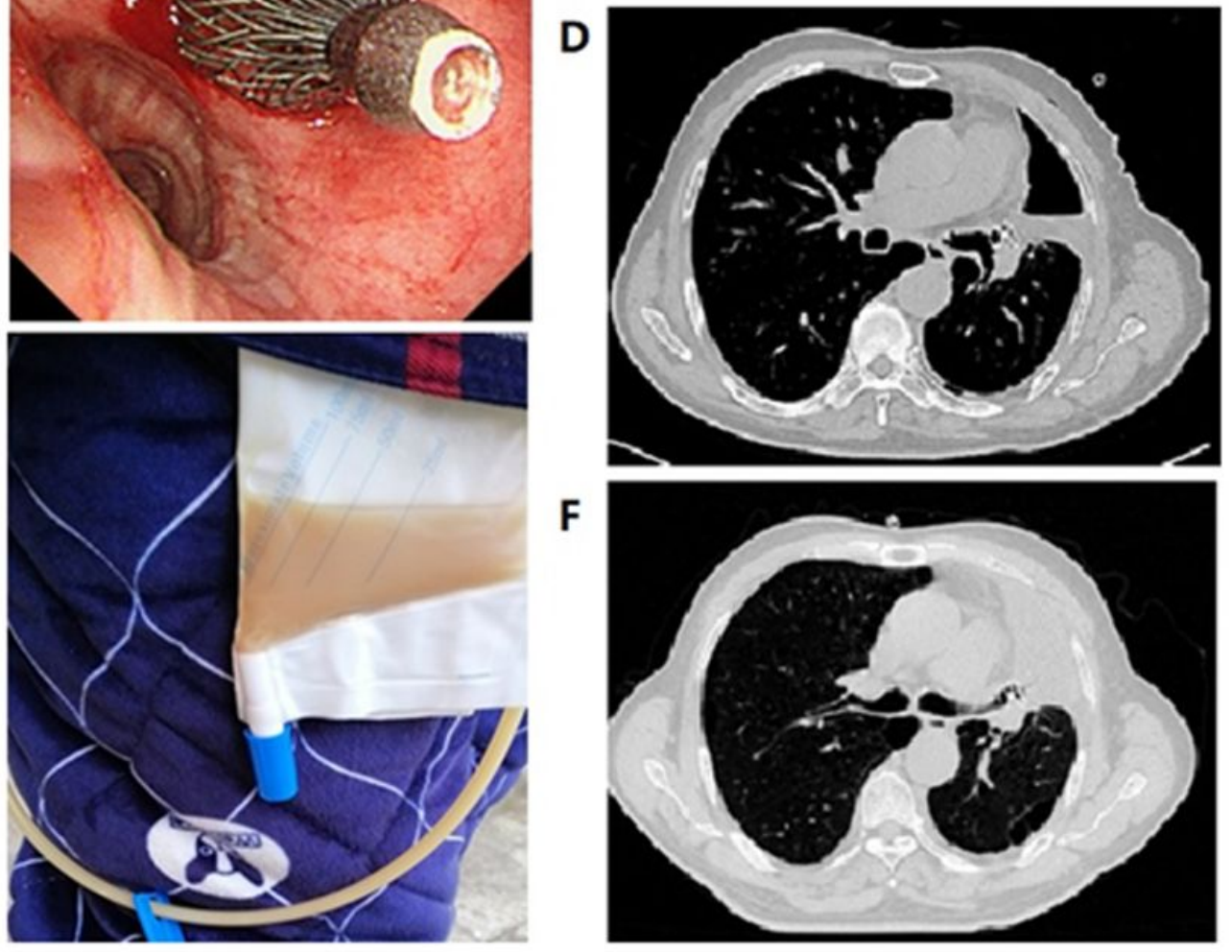

$\mathbf{F}$

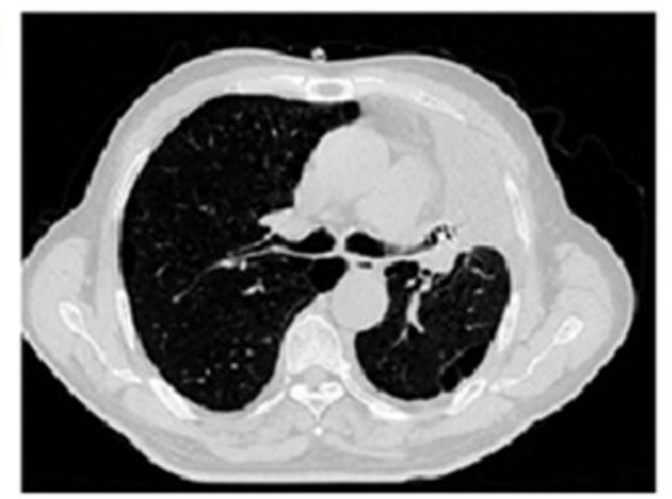

Figure 3

Bronchopleural fistula following left upper lobe lobectomy in patient No. 4. A, Chest CT before AD implantation. B, Bronchoscopy before AD implantation. C, Bronchoscopy after AD implantation. D, Chest CT after 1 month of $A D$ implantation. $E$, Water seal drainage bottle was changed to a drainage pack after 1 month of $A D$ implantation. F, Chest CT after 2 months of AD implantation, and the drainage tube was removed after CT scan. 
A

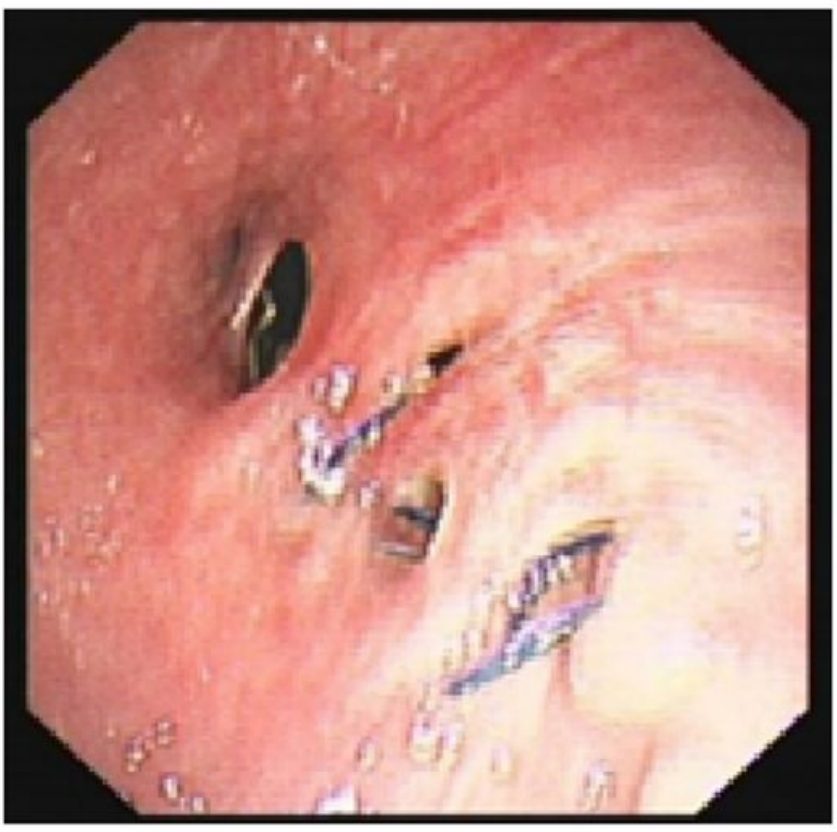

B

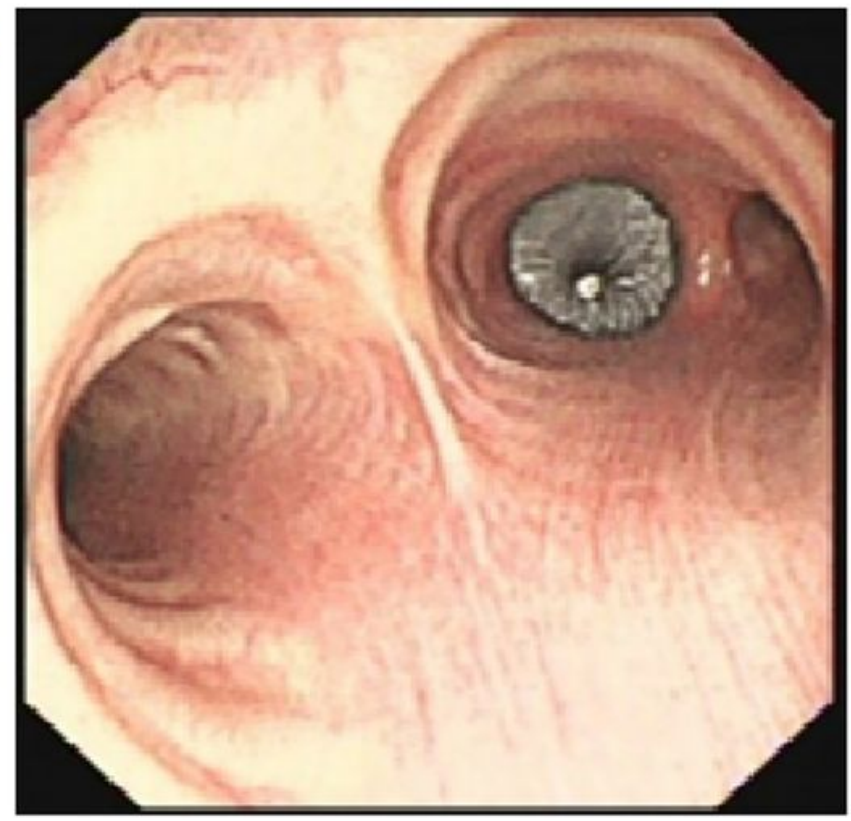

Figure 4

Bronchopleural fistula following right middle lobe and right lower lobe lobectomy in patient No. 6. A, Bronchoscopy before AD implantation. B, Bronchoscopy after AD implantation.

\section{Supplementary Files}

This is a list of supplementary files associated with this preprint. Click to download.

- video.mp4 